\title{
Internal Control Practices of Readymade Garments Sector (Textile Industry) in Bangladesh
}

\author{
Anup Kumar Saha ${ }^{1}$, Kartik Chandra Mondal ${ }^{2}$ \\ ${ }^{1}$ Department of Accounting and Information Systems, Jagannath University, Dhaka, Bangladesh; \\ ${ }^{2}$ Faculty of Business, ASA University Bangladesh, Dhaka, Bangladesh
}

\begin{abstract}
Internal control has a pivotal role in ensuring sustenance of any industry because it plays an important role in preventing and detecting fraud and protecting the organization's resources. This study has found many factors that are relevant for internal control practices in readymade garments (RMG) sector. These vary from maintenance of employees' job description to bonding employees with special access. In many variables these companies are practicing acceptable level of internal control, while in some they are not doing so good and have ample scope to improve that level. RMG sector is mainly populated with sole proprietorship firms and they do not allocate much resource to such practice. Even then the concern for internal control has to be implemented to ensure long lasting role in the economy.
\end{abstract}

Keywords: Readymade Garment (RMG) Industry, Internal Control (IC), Grievance Procedure, Corporate Code of Conduct, Cost-Benefit Analysis.

JEL Classification Code: L11; M11

\section{INTRODUCTION}

$T_{\mathrm{i}}$ HE role of the readymade garments (RMG) industry in the economy of Bangladesh can not be denied. RMG sector provides the largest contribution to the growing economy of this country. RMG is a success story so far for Bangladesh (Robbani, 2000). The industry has contributed to export earnings, foreign exchange earnings, employment creation, poverty alleviation and empowerment of women (Haider, 2007). Thus, its sustainability is of much importance for the development of the national economy. Internal control is one of the main ingredients to ensure the long term sustainability of any institution. It helps to ensure the attainment of the organizational goals. Thus, the internal control practices pursued by the companies in the RMG sector is one of the key determining factors of the sustainability of this sector. Recently, the pressure for increasing labor wages, both from labor and regulatory bodies, has influence over this sector. The operating costs of RMG companies are rising and placing profitability and sustainability at stake. The recent unrest for increasing labor wages has turned the situation more turbulent. All these risk- factors call for a pioneering study on the control system of this sector, so that it may be able to manage and control any likely adverse situation in future.

\section{Statement of The Problem}

Bangladesh depends a lot on its RMG sector for export income. The main player in the continual push for national development is the RMG sector; one could argue that RMG industry is the sole credible player in the national economy. The sustainability of this highly valuable sector is therefore, of much concern. This study focuses on the vigilance of internal control system and policy of companies in the RMG sector.

\section{Literature ReVIEW}

The ready-made garment (RMG) industry of Bangladesh started in the late 1970s and become a prominent player in the economy within a short period of time (Haider, 2007). He also found that Bangladesh needs to improve the factory working environment and various social issues related to RMG sector.

Delahanty (1999) found that average garment manufacturing labor cost in Bangladesh is $\$ 0.16$ per hour in 1993, while the corresponding figures for India and China were $\$ 0.27$ and 0.25 respectively in the same year. But the recent raise in RMG minimum wage has created a concern for this sector, which calls for greater control over cost minimization in the same sector as this was the driver behind the success of this industry.

Moreover, according to Paul-Majumdar (2001) rented factory premises, narrow staircases, low roofs, closed environments, absence of lunch rooms, unavailability of clean drinking water and no separate toilets or common rooms for female workers are other concerns in the garment factories of Bangladesh. These shortcomings in the physical infrastructure threaten the development of this sector.

Thus, previous research has shown that companies in the RMG industries need to address several shortcomings to maintain their position in the global market and continue contributing to the national economy.

Feng et al (2009) found a positive association between 
internal control and management forecast accuracy. They also found a positive relationship between management ability and implementation of strong internal controls, suggesting that internal controls may be one way to address these shortcomings. The concepts of corporate governance also heavily rely on the necessity of internal controls. Internal controls help ensure that processes operate as designed and that risk responses (risk treatments) in risk management are carried out. In addition, there needs to be in place circumstances ensuring that the aforementioned procedures will be performed as intended: right attitudes, integrity and competence, and monitoring by managers. Yet, previous studies have not reviewed the internal control practices in the RMG sector, neither internationally nor locally. While there are some studies on physical problems in the RMG sector, lack of attention to the system practices and development calls for pioneering research in this area.

\section{Methodology for The Study}

To collect information on internal control practices within the companies in the RMG sector, this study used survey method. A questionnaire, consisting of consisting of 18 separate questions was prepared. These questions were primarily close ended; additional questions captured descriptive comments. With a view to getting an overview of the current situation, 52 respondents were surveyed from 21 organizations or garments. The questions have been placed into five broad categories. These are as follows:

1. Management philosophy and operating style

2. Organization structure

3. Assignment of Authority and responsibility

4. Human resource policies and practices

5. Cost Benefit Analysis

Under each category, there are separate question(s) for the respondents. The complete survey appears in Appendix. Respondents are the members of top management of the chosen companies. These companies have been chosen on a convenience basis.

\section{AnAlysis of The StUdy Findings}

The internal control structure of the companies has been analyzed from five different perspectives.

\section{MANAGEMENT PHILOSOPHY AND OPERATING STYLE}

Seventy five percent of the respondents said that they emphasize short term profits and operating goals even to the detriment of long term goals; only the remaining twenty five percent emphasizes long term goals. This is quite a shocking finding, and this practice should be reconsidered. Half of the companies are dominated by only one or few individuals, limiting greater participation in decision making. On the other hand, thirty seven percent of the companies have quite healthy practice and have greater participation in their management. $13 \%$ preferred not to answer this question.

Of the studied companies, $44 \%$ are conservative toward selecting accounting policies, while an equal number of respondents $(44 \%)$ said they are aggressive in selecting from available alternative accounting policies. They think that aggressiveness is necessary for profitability.

\section{TABLE 1: RESPONSES TO QUESTIONS ON MANAGEMENT PHI-} LOSOPHY AND OPERATING STYLE

\begin{tabular}{|l|l|l|l|l|}
\hline \multicolumn{1}{|c|}{ Questions } & YES & NO & PNA & Total \\
\hline $\begin{array}{l}\text { Does management } \\
\text { emphasize short term } \\
\text { profits and operating } \\
\text { goals to detriment of } \\
\text { long term goals? }\end{array}$ & $75 \%$ & $25 \%$ & $0 \%$ & $100 \%$ \\
\hline $\begin{array}{l}\text { Is the management } \\
\text { group dominated by } \\
\text { one or a few individu- } \\
\text { als? }\end{array}$ & $50 \%$ & $37 \%$ & $13 \%$ & $100 \%$ \\
\hline $\begin{array}{l}\text { Is the management } \\
\text { conservative toward } \\
\text { selecting from availa- } \\
\text { ble alternative ac- } \\
\text { counting policies? }\end{array}$ & $44 \%$ & $44 \%$ & $12 \%$ & $100 \%$ \\
\hline
\end{tabular}

* PNA = Prefer not to answer

\section{Organization STRUCTURE}

Majority of the organizations (83\%) have an up to date organizational chart showing the names of the key personnel. Sixty percent of the RMG companies have separate and distinct internal audit function from the accounting unit. In thirty eight percent of those companies, the internal audit and accounting activities are done by the same persons. This indicates that these companies do not have any segregation of duties and the works done are not cross checked, which increases the likelihood of any fraudulent activities in the company. The rest $2 \%$ opted not to answer this question.

In half of the companies surveyed, subordinate managers report to more than one superior. In $44 \%$ of such cases, subordinates have only one superior for reporting purpose. This indicates the lack of proper distribution of authority in the companies.

TABLE 2: RESPONSES TO QUESTIONS ON ORGANIZATION STRUCTURE

\begin{tabular}{|l|l|l|l|l|}
\hline Questions & YES & NO & PNA & Total \\
\hline $\begin{array}{l}\text { Is the up to date organi- } \\
\text { zation chart prepared, } \\
\text { showing the names of } \\
\text { key personnel? }\end{array}$ & $83 \%$ & $17 \%$ & $0 \%$ & $100 \%$ \\
\hline $\begin{array}{l}\text { Is the internal audit } \\
\text { function separate and } \\
\text { distinct from account- } \\
\text { ing? }\end{array}$ & $60 \%$ & $38 \%$ & $2 \%$ & $100 \%$ \\
\hline $\begin{array}{l}\text { Do subordinate manag- } \\
\text { ers report to more than } \\
\text { one superior? }\end{array}$ & $50 \%$ & $44 \%$ & $6 \%$ & $100 \%$ \\
$* P N A=$ Prefer not to answer
\end{tabular}




\section{ASSIGNMENT OF AUTHORITY AND RESPONSIBILITY}

Quite a big portion (92\%) of the companies surveyed, have written job descriptions for its employees defining specific duties and reporting relationships. Only a small portion $(6 \%)$ does not have such job description. Without definite job description there may show up lack of direction, goal and enthusiasm. Sixty nine percent respondents said that there is a requirement for written approval before any changes can be made to present information systems. A quarter of the respondents denied having any such existing requirements in their company. This indication conforms the lack of adequate assignment of authority and responsibility in organizations.

Seventy four percent of the companies clearly delineate the boundaries of authority and responsibility relationship to employees and managers. Half of the remaining twenty six percent do not have delineation of authority and responsibility to employees and managers and other half $(13 \%)$ did not respond to the question.

In sixty two percent of the companies, there is a system of proper delegation of authority to employees and departments. On the other hand, twenty three percent of the companies do not have such systematic delegation system of authority. Delineation and of the boundaries and delegation are important because these are ways by which a manager multiples himself and is able to bring stability, ability and soundness to a concern.

TABLE 3: RESPONSES TO QUESTIONS ON ASSIGNMENT OF AUTHORITY AND RESPONSIBILITY

\begin{tabular}{|l|l|l|l|l|}
\hline Questions & YES & NO & PNA & Total \\
\hline $\begin{array}{l}\text { Does the company pre- } \\
\text { pare written employee job } \\
\text { descriptions defining spe- } \\
\text { cific duties and reporting } \\
\text { relationships? }\end{array}$ & $92 \%$ & $6 \%$ & $2 \%$ & $100 \%$ \\
\hline $\begin{array}{l}\text { Is written approval re- } \\
\text { quired for changes made } \\
\text { to information systems? }\end{array}$ & $69 \%$ & $25 \%$ & $6 \%$ & $100 \%$ \\
\hline $\begin{array}{l}\text { Does the company clearly } \\
\text { delineate to employees } \\
\text { and managers the boun- } \\
\text { daries of authority- } \\
\text { responsibility relation- } \\
\text { ships? }\end{array}$ & $74 \%$ & $13 \%$ & $13 \%$ & $100 \%$ \\
\hline $\begin{array}{l}\text { Does the company proper- } \\
\text { ly delegate authority to } \\
\text { employees and depart- } \\
\text { ments? }\end{array}$ & $62 \%$ & $23 \%$ & $15 \%$ & $100 \%$ \\
\hline
\end{tabular}

${ }^{*}$ PNA $=$ Prefer not to answer

\section{HUMAN RESOURCE POLICIES AND PRACTICES}

Eighty five percent of the companies train their new employees about internal controls, ethical policies, and corporate code of conduct; in $8 \%$ of companies such training is not present. Absence of such an orientation program for new employees may have an adverse effect in terms of control and achievement of intended goal. In this case,
$7 \%$ decided not to respond.

Grievance procedure should be in place to maintain a healthy environment within any organization. In this study, findings revealed that $56 \%$ companies have this practice in some form. Thirty three percent of the companies have not implemented any such procedure for their employees. The remaining $11 \%$ of the respondents preferred not to state anything regarding this issue.

A sound employee relations program is maintained by $90 \%$ of the companies, which show their commitment to healthy employee relation within the organization. Only six percent of the companies do not have any such program in place. The other four percent of the respondent remain silent regarding this matter.

The respondents said that in eighty five percent of the cases employees work in safe and healthy environment. It should be remembered that all the respondents are from management group in this study of internal control. So, the responses from them show that they believe their organizations are maintaining safe and healthy environment in workplaces. However, the recent unrest in garments sector for upgradation of minimum wages unveils another picture. One of these is lack of safety in the workplaces, with many fire breakouts. These reports indicate there is still a long way to go to maintain a safe and healthy work environment in the RMG sector. Of the remaining $15 \%$ of the respondents, $13 \%$ admit that safety and healthiness in workplace has not been still implemented in their organizations.

In $62 \%$ of the cases, counseling program is said to be available and in action. One fourth of the respondents said that counseling program is not still in place for the employees, while the remaining $13 \%$ were silent when asked about this issue.

Employees may decide to leave the organization because of personal reasons, better opportunity, change of career, grievance from present job etc. All those employees who leave should be properly separated through a well managed program. This would ensure the confidentiality of information and goodwill to the company. It is essential to maintain a good control over information resources, and make sure that individuals learning the organization do not have access to company information. Less than half of the respondents said that they have such separation programs in force for employees who leave the firm. Employees who have access to cash and other negotiable instruments are bonded in thirty seven percent of the cases. On the other hand, thirty eight percent of the companies do not have any such policy to bond employees having such access to cash and negotiable instruments. Remaining one fourth of the respondents did not answer this question. This may be due to the skepticism against bonds. 
TABLE 4: RESPONSES TO QUESTIONS ON HUMAN RESOURCE POLICIES AND PRACTICES

\begin{tabular}{|l|l|l|l|l|}
\hline Questions & YES & NO & PNA & Total \\
\hline $\begin{array}{l}\text { Are new personnel indoc- } \\
\text { trinated with respect to } \\
\text { internal controls, ethics } \\
\text { policies, and corporate } \\
\text { code of conduct? }\end{array}$ & $85 \%$ & $8 \%$ & $8 \%$ & $100 \%$ \\
\hline $\begin{array}{l}\text { Are grievance procedures } \\
\text { to manage conflict in } \\
\text { force? }\end{array}$ & $56 \%$ & $33 \%$ & $12 \%$ & $100 \%$ \\
$\begin{array}{l}\text { Does the company main- } \\
\text { tain a sound employee } \\
\text { relations program? }\end{array}$ & $90 \%$ & $6 \%$ & $4 \%$ & $100 \%$ \\
\hline $\begin{array}{l}\text { Do employees work in } \\
\text { safe, healthy environ- } \\
\text { ments? }\end{array}$ & $85 \%$ & $13 \%$ & $2 \%$ & $100 \%$ \\
\hline $\begin{array}{l}\text { Are counseling programs } \\
\text { available? }\end{array}$ & $62 \%$ & $25 \%$ & $13 \%$ & $100 \%$ \\
\hline $\begin{array}{l}\text { Are proper separation } \\
\text { programs in force for } \\
\text { employees who leave the } \\
\text { firm? }\end{array}$ & $46 \%$ & $38 \%$ & $15 \%$ & $100 \%$ \\
\hline $\begin{array}{l}\text { Are employees who have } \\
\text { access to cash and other } \\
\text { negotiable instruments } \\
\text { bonded? }\end{array}$ & $37 \%$ & $38 \%$ & $25 \%$ & $100 \%$ \\
\hline
\end{tabular}

${ }^{*}$ PNA $=$ Prefer not to answer

\section{Cost Benefit Analysis}

Overall, seventy six percent of the respondents think that internal control practices offer benefit greater than the cost involved to the organization. While eight percent of the respondents think otherwise.

TABLE 5: RESPONSES TO QUESTIONS ON COST-BENEFIT ANALYSIS

\begin{tabular}{|l|l|l|l|l|}
\hline \multicolumn{1}{|c|}{ Questions } & YES & NO & PNA & Total \\
\hline Are the internal control & & & & \\
practices in your organi- & & & & \\
zation offering any benefit & $76 \%$ & $8 \%$ & $16 \%$ & $100 \%$ \\
to your organization at \\
all? If yes, how?
\end{tabular}

${ }^{*}$ PNA $=$ Prefer not to answer

Respondents listed several benefits derived from superior internal control policy in the organization. It helps in decision making, increases efficiency of internal operations, identifies and reduces financial, human resources, technological and political risks, increases financial security and excellence, helps to focus on future rather than past, ensures control over the organization and resources, maximization of profit, minimizes cost from savings, time savings, helps proper evaluation of perfor- mances, managing large employee groups, maintains discipline and ensures safety of employees and resources, helps to deal with operations related to supply chain, and ensures good corporate governance.

\section{Conclusion AND Suggestion Further RESEARCH}

The goal of this study is to obtain a concrete idea of the effectiveness of internal control practices in the readymade garments sector in Bangladesh. The RMG sector contributes considerably to the development of the national economy of Bangladesh. Majority of the foreign export income comes from this sector, thus it has an enormous role on the economy. The recent unrest in this sector suggests the need for purposeful evaluation of the sustainability of this industry. The push for minimum wage increase and maintenance of a safe working environment were the reasons for recent unrest. To avoid such problems and to ensure the long lasting presence of this promising sector, the control system should be strengthened. This study presents a picture of the present situation in this respect.

The responses to the eighteen questions asked to the respondents suggest that some improvements need to be made. However, majority of the organization do have control systems in place. Less than fifty percent of the respondents reported that -

1. the institution is actually not maintaining conservatism while choosing from alternative accounting policies,

2. there is no proper separation programs for employees who leave the firm and

3. employees are not bonded who have access to cash and negotiable instruments.

This study includes respondents from management only. A future study including respondents from representatives of management, labor and regulatory groups would discover if there is agreement between these stakeholders. No relationship has been developed between the benefits derived from the internal control practices and the costs involved. A cost benefit analysis could be done as well. Another probable research area can be the relationship between organizational profitability and effectiveness \& efficiency of internal control in place in that organization to verify the contribution of internal control to the profitability.

\section{REFERENCES}

[1] Ashbaugh-Skaife, H., Collins, D., Kinney, W., LaFond, R., 2008. Internal control deficiencies, remediation and accrual quality. The Accounting Review 83 (1), 217-250.

[2] Beneish, D., Billings, M., Hodder, L., 2008. Internal control weaknesses and information uncertainty. The Accounting Review 83, 665-703.

[3] Birnberg, J.B., Shields, M.D. and Young, S.M. 1990. The case for multiple methods in empirical management accounting research (with an illustration of budget setting). Journal of Management Accounting Research, Fall, 33-66. 
[4] Delahanty, Julie, 1999. A Common Thread: Issues for Women Workers in the Garment Sector, report prepared for the Global Markets Programme of Women in Informal Employment: Globalizing and Organizing. Ottawa, North-South Institute.

[5] DeFond, M., Raghunandan, K., Subramanyam, K.R., 2002. Do nonaudit service fees impair auditor independence? Evidence from going concern audit opinions. Journal of Accounting Research 40, 1247-1274.

[6] Doyle, J., Ge, W., McVay, S., 2007b. Determinants of weaknesses in internal control over financial reporting. Journal of Accounting and Economics 44, 193-223.

[7] Feng, Mei; Li, Chan and McVay, Sarah, 2009. Internal Control and Management Guidance. Journal of Accounting and Economics, pp 150.

[8] Haider, Mohammed Z., 2007. Competitiveness of the Bangladesh Ready-made Garment Industry in Major International Markets, Asia Pacific Trade and Investment Review, Vol 3 No 1, June. Pp3-26.

[9] Lang, M., Lundholm, R., 1996. Corporate disclosure policy and analyst behavior. The Accounting Review 71 (4), 467-492.

[10] Neimark, M. \& Tinker, A.M. 1986. The Social Construction of Man- agement Control Systems. Accounting, Organisations \& Society, 11, 45:369-395.

[11] Paul-Majumdar, Pratima, 2001. 'Occupational Hazards and Health Consequences of the growth of garment industry in Bangladesh', in Pratima Paul-Majumdar and Binayak Sen, eds., Growth of Garment Industry in Bangladesh: Economic and Social Dimensions (Dhaka, Bangladesh Institute of Development Studies and Oxfam GB, Bangladesh).

[12] Robbani, M Golam, 2000. World Trade Organization and The Readymade Garment Industry of Bangladesh: A critical Analysis, Journal of Bangladesh Studies, University of Pennsylvania, USA, pp 16 - 27.

[13] Rogers, J., Stocken, P., 2005. Credibility of management forecasts. The Accounting Review 80, 1125-1162.

[14] Wilkinson, Joseph W. and Cerullo, Michael J., . Accounting Information Systems, Fourth edition, John Wiley \& Sons, Inc. pp 247-364.

[15] Willis David M. and Lightle Susan S., 2000. Management Reports on Internal Controls- What do they say about your company?, Journal of Accountancy, AICPA.



